Marco Aurélio Silva Lipay, Irene de Lourdes Noronha Armando Vidonho Júnior, João Egídio Romão Júnior João Carlos Campagnari, Miguel Srougi

\title{
Lymphocele: a possible relationship with acute cellular rejection in kidney transplantation
}

Urology and Nephrology Clinic, Beneficência Portuguesa Hospital, São Paulo, Brazil

\section{ABSTRACT}

CONTEXT: The incidence of lymphocele after renal transplantation varies between 0.6 and $18 \%$ of cases, and many factors have been associated to its etiology. Cellular rejection of the kidney allograft has been described as a possible causal factor of lymphocele.

OBJ ECTIVE: To analyze the possible relationship between lymphocele and acute cellular rejection.

DESIGN: A retrospective study.

SETTING: A referral hospital center.

SAMPLE: 170 patients submitted to kidney transplantation from March 1992 to January 1997. A standard technique for renal transplantation was used.

RESULTS: 0 f the 19 patients that developed lymphocele, 16 presented at least one episode of acute cell rejection $(84 \%)$, and were treated with methylprednisolone. The relation between lymphocele and rejection was statistically significant $(p=0.04)$. Treatment of lymphocele consisted of peritoneal marsupialization in 3 patients (15.3\%), percutaneous drainage in $7(36.8 \%)$, laparascopic marsupialization in $2(10.5 \%)$, and conservative treatment in 7 patients $(36.8 \%)$. Evolution was favorable in 15 patients $(78.9 \%), 1$ patient $(5.3 \%)$ died due to a cause unrelated to lymphocele, and $3(15.8 \%)$ lost the graft due to immunological factors. The average follow-up period was 24.5 months.

CONCLUSION: The high incidence of acute cell rejection in patients with lymphocele suggests a possible causal relationship between both conditions.

KEY WORDS: Kidney transplantation. Rejection.

Lymphocele
INTRODUCTION

The incidence of lymphocele after renal transplantation varies between 0.6 and $18 \%$ of cases, $^{1,2}$ and many factors have been associated to its etiology. Among these factors, iliac fossa preparation, kidney biopsy, diuretics and the use of corticosteroids in high doses should be mentioned.

Cellular rejection of the kidney a llog raft has been described as a possible causal factor of lymphocele. ${ }^{5}$ This immunological phenomenon leads to an intense local inflammatory process and an increase in regional lymph flow.

The present study analyzed the possible association between lymphocele and acute cellular rejection 170 kidney transplantations.

\section{METHODS}

0 ne hundred and seventy patients, $(90$ male and 60 female) submitted to renal transplantation between March 1992 and January 1997 were studied retrospectively in the Urology and $\mathrm{N}$ ephrology Clinic of Beneficência Portuguesa Hospital.

The surgical technique used for kidney transplantation was the retroperitoneal a pproach 
in the iliac fossa, with dissection of iliac vessels and bladder dome, and ligatures with nonabsorbable sutures (cotton 4.0) and avoiding the use of electrocautery.

The graft was perfused with Euro-Collins or Belzer perfusion solutions for maintenance, followed by bench surgery with special care in the hilum region, and performing vascular and lymphatic ligatures with non-absorbable sutures (cotton 5.0).

A triple therapy with azathioprine, prednisone and cyclosporin was used for immunosuppression. The diagnostic of acute cellular rejection was obtained by analysis of the clinical data, which included an increase in serum creatinine, a decrease in diuresis, eosinophilia and fever, after discarding vascular obstructions and urological disorders. A percutaneous renal biopsy was also obtained if needed to validate the diagnosis. A cute cellular rejections were treated with methylprednisolone ( $1 \mathrm{~g} /$ day) for three days and monoclonal orthoclone antibody was used (0 KT3) in corticoresistant rejection cases.

Pelvic ultrasonography was carried out routinely on the fifth postoperative day and whenever clinically necessary. The period for diagnosing lymphoceles by this imaging method was four to 93 postoperative days (average 35).

Lymphoceles were defined as the presence of perirenal fluid collection with a diameter greater than $5 \mathrm{~cm}$, diagnosed after the first postoperative week. It was classified as symptomatic when associated to local and/ or systemic signs and symptoms.

Surgical treatment was carried out in cases of symptomatic lymphocele with systemic repercussion. Surgical treatment was preceded by aspirative percutaneous puncture, guided by ultrasound, and also biochemical analysis and fluid culture.

Whenever there was evidence of lymphocele recurrence without signs of infection, internal drainage was performed (open or laparascopic peritoneal marsupialization). In case of infected lymphocele, external drainage was performed (closed drainage system). The average follow-up period was 24.5 months.

All results were submitted to statistical analysis using Fisher's exact test, considering a $p$-value $<0.05$ as statistically significant.

\section{RESULTS}

A mong the 170 kidney transplants studied, 106 patients $(62.5 \%)$ developed acute cellular rejection and 19 (11.2\%) had a diagnosis of lymphocele within an average period of 48.5 days (range 9 to 156).

Table 1 shows that among the 19 patients that developed lymphocele, 16 (84\%) had at least one episode of acute cellular rejection, and acute rejection was developed by 90 (59.6\%) of the remaining 151 patients that did notpresent Iymphocele. The relation found between lymphocele and rejection was statistically significant $(p=0.04)$. A mong the sixteen patients with lymphocele that evolved with acute cellular rejection, ten $(62.5 \%)$ were submitted to renal percutaneous biopsy with diagnostic confirmation. The acute cellular rejection had clinical manifestation between 3 to 50 days (average of 10 days) and the diagnosis of lymphocele occurred between the $7^{\text {th }}$ and the $64^{\text {th }}$ day post-surgery (average of 27.5 days).

Considering the 19 lymphoceles, 12 (63\%) were symptomatic and needed surgical intervention, preceded by a negative culture in all cases. Thus, ultra sound guided percutaneous drainage was carried out in 7 patients $(36.8 \%)$, marsupialization in $3(15.7 \%)$, and laparoscopic marsupialization in $2(10.5 \%)$. The remaining 7 asymptomatic patients (36.8\%) were submitted to conservative treatment with ultrasound and laboratory test follow-up.

In three of the seven cases of symptomatic lymphoceles in which patients were submitted to percutaneous drainage, peritoneal marsupialization was necessary due to the development of recurrent fluid collection. M oreover, the method failed with recurrence of collection in two patients submitted to laparoscopic marsupialization. 0 ne of these patients was submitted to percutaneous drainage and the other to celiotomy (Table 2). 
The treatment developed favorably in 15 (78.9\%) patients, 3 (15.8\%) patients lost the graft due to immunological causes, and one $(5.3 \%)$ died due a cause not related to the procedure. An average 24.5 month (range 3 to 53 months) follow-up period was maintained.

\section{DISCUSSION}

Kidney transplantation is currently the treatment of choice for patients in a terminal stage of chronic kidney failure. This is not, how ever, a procedure free of surgical complications.

Lymphocele is a surgical complication with a described incidence between 0.6 and $18 \%$ of patients submitted to renal transplantation, presenting symptoms in $36 \%$ of cases with perirenal fluid collections above $100 \mathrm{ml}^{1,2}$ The variation in frequency in different transplant centers may be justified by the absence of a standardized definition of complicated lymphocele, as the routine and early use of ultrasonography provides a diagnosis of lymphocele without clinical consequences.

The clinical observation that a significant proportion of the patients that presented acute cellular rejection had developed lymphocele suggests that there may be a direct association between these problems, which were considered statistically significant, but it has not yet been possible to establish any physiopathological cause directly related to these problems.

Data from the present study revealed a general incidence of $11.2 \%(19 / 170)$ of lymphocele after renal transplantation, of which $9.4 \%(16 / 170)$ had at least one episo de of acute cellular rejection, and only $1.7 \%(3 / 170)$

Table 1 - Profile of transplanted patients that developed with or without rejection and lymphocele*

\begin{tabular}{|c|c|c|c|}
\hline \multirow[b]{2}{*}{ Lymphocele } & \multicolumn{2}{|c|}{ Rejection } & \multirow[b]{2}{*}{ Total } \\
\hline & $W$ ith & W ithout & \\
\hline Present & $16(84 \%)$ & $03(16 \%)$ & 19 (11.2\%) \\
\hline Absent & 90 & 61 & 151 \\
\hline Total & 106 & 64 & 170 \\
\hline
\end{tabular}

*Fisher exact test $(\mathrm{P}<0.05)$ presented lymphocele without acute rejection. Braun et al ${ }^{9}$ reported 15 patients (18.1\%) with lymphocele among 83 renal transplantations. These authors highlighted factors that alter the lymphatic flow of either the graft or the receptor (surgical dissection, rejection, use of diuretics and high doses of corticosteroids) as possible causes of lymphocele. Pollak et al ${ }^{1}$ found 35 cases of lymphocele $(9 \%)$ and of these, $13(37.1 \%)$ were related to episodes of a cute cellular rejection.

Khauli et al ${ }^{5}$ suggested that allograft rejection is the most powerful risk factor contributing to lymphoceles following renal transplantation. In addition these authors emphasized the importance of other sources of lymphoceles, especially the care taken during surgical techniques. Barroso et al ${ }^{10}$ emphasized the importance of surgical care, reporting a rate of $1.1 \%$ symptomatic lymphoceles among 356 renal transplantations. However no relation between lymphocele and cellular rejection was reported in their cases.

A nother source of lymph is the three plexuses of the kidney graft. Two are intra-renal plexuses, one around the kidney tubules and a nother around the subcapsular region. The third is an extra-renal plexus, along the perirenal fat, which communicates with the intra-renal plexus that drains hilum branches into renal vessels running towards lateral a orta branches and paracava nodules. The ligation of lymphatic branches emerging from the graft hilum can thus be justified.

Excluding surgical factors, other causes of lymphocele are allograft biopsies, arteriovenous fistulas, use of diuretics, high doses of corticosteroids and anticoagulants, and especially episodes of acute cellular rejection.

Renal allograft rejection is immunologically mediated and involves humoral and cellular response. Cellular rejection is more frequent in the first three months after transplantation, and is characterized by a set of signs and symptoms and impairment of kidney function. The rejection generally responds quickly and satisfactorily to corticosteroids, which in most cases revert the 
stimulated state of the autoimmune system that is manifested via intense inflamma tory processes and increased local flow of effluents.

A possible mechanism to explain the increased flow of lymph from the kidney during cellular rejection was demonstrated by Pedersen and Moris. ${ }^{6}$ These authors used a sheep model in which the kidney was implanted in the neck of the animals. They recorded the flow of the effluent after cannulating lymph ducts of the graft. A 20 to 50 fold increase in flow was observed during rejection, in comparison to auto-transplant, indicating that an immunological factor related to the transplanted kidney may be involved in the genesis of the process.

Castilho et $\mathrm{I}^{11}$ observed episodes of cellular rejection before the diagnosis of lymphocele in $60 \%$ of patients studied, while Kauli et $\left.\right|^{5}$ analyzed the risk factors involved statistically in lymphocele in 118 kidney transplants, and observed $6.8 \%$ symptomatic lymphoceles up to 3.7 years after transplantation. The latter authors concluded that only acute cellular rejection episodes were related to lymphocele diagnosis.

The risk factors observed in the present study, such as the surgical technique and graft biopsy, did not show statistical significance when correlated to the physiopathology of lymphocele, with the exception of a cute cellular rejection ( $P=0.04)$ and possibly therapeutic use of corticosteroids (Table 1 ).

The data of the present study are similar to those of other reports which have shown an incidence of up to $75 \%$ of symptomatic lymphocele associated with episodes of cellular rejection treated with corticosteroids. ${ }^{1,2,5}$ These risk factors have also been described by other authors, ${ }^{2,5}$ although the number of cellular rejection episodes or doses of steroids administered in each case ${ }^{2,5}$ are notalways clear. These factors may result in different types of inflammatory response, justifying the increased lymphatic flow and graft volume, thus maintaining lymphocele in some cases.

Diagnosis, control and management of perirenal fluid collection after transplantation not only becomes more efficient and safer with the use of ultrasonography, ${ }^{5,11}$ but also contributes to complicating the definition in relation to volume, symptoms and clinical features. Khauli et $a 1^{5}$ observed spontaneous resolution of lymphocele in $86 \%$ of cases, although Pollak et al $1^{5}$ analyzed 386 kidney transplants and found 190 cases $(49 \%)$ of perirenal collections, of which 98 patients (51\%) were clinically asymptomatic and presented a volume below 50 $\mathrm{ml}$ that disappeared spontaneously during followup. The remaining patients $(49 \%)$, presented collections between 51 and $100 \mathrm{ml}$ and had associated or suspected symptoms of cellular rejection, demanding some type of surgical approach.

W henever lymphocele is symptomatic, the size of the collection, the period of evolution and the symptoms should be considered, as well as excluding the presence of infection caused by previous puncture techniques. In the presentstudy, we chose to perform surgery in 12 patients $(63 \%)$ with symptomatic lymphocele, i.e. $7 \%$ of the kidney transplants.

According to A mante et al, ${ }^{4}$ the treatment of choice for draining symptomatic lymphocele is peritoneal marsupialization, with a success rate between 80 and $90 \%$. The management followed in the present study was analyzed individually and presented positive results in $78.9 \%$ of the cases. When laparoscopic marsupialization was chosen (2 cases), a second intervention was necessary with a percutaneous puncture in one case, and peritoneal marsupialization in another.

According to data from $\mathrm{G}$ ruessner et al, ${ }^{11}$ laparoscopy is a feasible technique with a success rate of $64 \%$ and should be used routinely.

Table 2 - Initial procedures in 19 patients that developed lymphocele after kidney transplantation

Percutaneous drainage

$7(36.8 \%)$

Peritoneal marsupialization

$3(15.7 \%)$

Laparoscopic marsupialization

$2(10.5 \%)$

Conservative treatment 
However, it is a limited method when the collection is anterior or supra-lateral to the graft, associated with a risk of ureteral or vascular lesion, or intestinal obstruction, possibly recurring in 35\% of cases. ${ }^{4,11}$ The contraindication to incision or laparoscopic peritoneal marsupialization of lymphoceles is the presence of infection.

\section{CONCLUSION}

The higher frequency of acute cellular rejection found in our patients with lymphocele suggests a possible causal relation between the two conditions. Further studies should be carried out to define whether cellular rejection is a causal factor for lymphocele or if the association only relates to higher doses of corticosteroids.

\section{REFERENCES}

1. Bry J, Hulld D, Bartus AS, Schweizer TR. Treatment of recurrent Iymphoceles following renal transplantation. Transplantation 1990;49:477-80.

2. Pollak R, Varemis A, Maddux SM, Mozes FM. The natural history and therapy for perirenal fluid collections following renal transplantation. J Urol 1988;140:716-20.

3. Mundy AR, Podesta ML, Bewick M, Rudge CJ, Ellis FG. The urological complication of 1000 renal transplantations. Br J Urol 1986;53:397-402.

4. Amante AJM, Kahan BD. Technical complications of renal transplantation. Surg Clin North Am 1994;75:1117-31.

5. Khauli RB, StoffJF, Lovewell T, Ghavamian R, Baker S. Post-transplant lymphoceles: a critical look into the risk factors, pathophysiology and management. J Urol 1993;150:22-6.

6. Pedersen NC, Moris B. The role of the lymphatic system in the rejection of homograft: a study of lymph from renal transplants. J Exp Med 1970;131:936-69.
7. Sagalowsky IA, Hinnant-Jr C, Cohen SM, Resnickz I. In: Nonvascular complications of renal transplantation - preoperative urology. $1^{\text {st }}$ ed. Philadelphia: WB Saunders; 1995:19-25.

8. Castilho LN, Ferreira U, Liang LS, Fregonesi A, Netto-Jr NR. Linfocele pós transplante renal: tratamento video laparoscópico: relato de cinco casos e revisão de literatura. J Bras Urol 1997;23:17-22.

9. Braun WE, Banowsky LH, Straffon RA, et al. Lymphoceles associated with renal transplantation: report of 15 cases and review of the literature. Am J Med 1974;57:714-29.

10. Barroso-Jr U, Lipay MAS, D'Avila CLR, et al. Complicacões cirúrgicas pós transplante renais: análise de 356 casos. J Bras Urol 1997;23:71-6.

11. Gruessner RWG, Fasola C, Benedetti E, et al. Laparoscopic drainage of lymphocele after kidney transplantation: indications and limitations. Surgery 1995:117;288-95.

12. Kalil J. Imunologia do transplante renal. In: Princípios de nefrologia e distúrbios hidroeletrolíticos. $3^{\text {rd }}$ ed. São Paulo: Savier; 1995:646-56.

Marco Aurélio Silva Lipay - PhD. Urology. Clinic of Hospital Beneficência Portuguesa. São Paulo, Brazil. Irene de Lourdes Noronha - PhD. N ephrology. Clinic of Hospital Beneficência Portuguesa. São Paulo, Brazil. Armando Vidonho Júnior - M D. N ephrology. Clinic of Hospital Beneficência Portuguesa. São Paulo, Brazil.

J oão Egídio Romão Júnior - PhD. N ephrology. Clinic of Hospital Beneficência Portuguesa. São Paulo, Brazil. J oão Carlos Campagnari - PhD. Urology. Clinic of Hospital Beneficência Portuguesa. São Paulo, Brazil. Miguel Srougi - M D, PhD. U rology (Chairman). Clinic of Hospital Beneficência Portuguesa. São Paulo, Brazil.

Sources of funding: $\mathrm{N}$ ot declared

Conflict of interest: $\mathrm{N}$ ot declared

Last received: 9 A pril 1999

Accepted: 7 M ay 1999

Address for correspondence:

Marco A urélio Silva Lipay

Rua Apucarana, 326 - cjto. 44-46

São Paulo/ SP - Brasil - CEP 04054-000

E-mail: mlipay@mobinet.com.br

RESUMO

CONTEXTO: A incidência de linfocele em pacientes submetidos a transplante renal varia entre 0,6 e $18 \%$ e vários são os fatores relacionados à sua etiologia. A rejeição celular do aloenxerto renal tem sido descrita como um possível fator etiológico das linfoceles. OBJETVO: Verificar a possível associação entre a ocorrência de linfocele e a rejeição celular aguda em transplante renais. TIPO DE ESTUDO: Estudo retrospectivo. AMOSTRA: 170 pacientes transplantados no período de março de 1992 a janeiro de 1997. LOCAL: Centro de referência hospitalar. RESULTADOS: Dos 19 pacientes que evoluíram com linfocele, 16 apresentaram pelo menos um episódio de rejeição celular aguda (84\%), todos tratados com metilpredinisolona. A relação entre linfocele e rejeição foi estatisticamente significativa $(p=0.04)$. 0 tratamento da linfocele foi realizado através de marsupialização peritoneal em 3 (15,3\%) pacientes, drenagem percutânea em 7 (36.8\%), marsupialização laparoscópica em $2(10,5 \%)$ e tratamento conservador em 7 (36.8\%). A evolução foi favorável em 15 (78.9\%), 1 (5,3\%) foi a óbito por causa não relacionada à linfocele e $3(15,8 \%)$ perderam o enxerto devido a fatores imunológicos. 0 período médio de acompanhamento desssa casuística foi de 24,5 meses. CONCLUSÃO: A maior freqüência de rejeição celular aguda encontrada no presente estudo, em pacientes com linfocele, sugere uma possível relação causal entre essas duas entidades.

PALAVRAS-CHAVE: Transplante renal. Rejeição. Linfocele 